\title{
The Physical, Chemical, and Biological Effects of Crude Oil Spills after 15 Years on a Black Spruce Forest, Interior Alaska
}

\author{
CHARLES M. COLLINS, ${ }^{1}$ CHARLES H. RACINE' ${ }^{\prime}$ and MARIANNE E. WALSH'
}

(Received 9 June 1993; accepted in revised form 8 December 1993)

\begin{abstract}
The effects of two large experimental crude oil spills conducted in the winter and summer of 1976 in a permafrost-underlain black spruce forest of interior Alaska were assessed 15 years after the spills. Effects on permafrost, as determined from measurements of active layer thaw depths and of the total amount of ground subsidence, were far more pronounced on the winter spill due to a larger surface-oiled area. The winter spill also had a more drastic effect on the vegetation. Where the black, asphalt-like surface oil was present, black spruce mortality was $100 \%$ and there was very little live plant cover except for cotton grass tussocks. Changes in oil chemistry varied with depth; surface samples had signs of microbiological degradation, whereas some subsurface samples taken just above the permafrost had no evidence of degradation and still contained volatile fractions.
\end{abstract}

Key words: crude oil, spill, terrestrial, taiga, permafrost, black spruce forest, interior Alaska

RÉSUMÉ. Quinze ans après avoir effectué deux grands déversements expérimentaux de pétrole brut durant l'hiver et l'été de 1976 dans une forêt d'épinettes noires reposant sur le pergélisol de l'intérieur de l'Alaska, on en a évalué les répercussions. Celles sur le pergélisol, déterminées d'après les mesures de la profondeur de fonte du mollisol et de la subsidence totale du sol, étaient beaucoup plus prononcées pour le déversement ayant eu lieu en hiver, en raison de la plus grande superficie couverte de pétrole. Ce déversement avait aussi eu des répercussions plus radicales sur la végétation. Là où le pétrole de surface ressemblant à de l'asphalte était présent, le taux de mortalité de l'épinette noire était de $100 \mathrm{p}$. cent et le couvert végétal vivant était rare, mis à part des buttes de linaigrette de Scheuchzer. Les changements dans la composition chimique du pétrole variaient avec la profondeur; les échantillons de surface montraient des signes de dégradation microbiologique, tandis que certains échantillons de subsurface prélevés juste au-dessus du pergélisol ne montraient aucun signe de dégradation et renfermaient encore des fractions volatiles.

Mots clés : pétrole brut, déversement, terrestre, forêt boréale, pergélisol, forêt d'épinettes noires, intérieur de l'Alaska

Traduit pour Arctic par Nésida Loyer.

\section{INTRODUCTION}

The discovery of oil at Prudhoe Bay on the North Slope of Alaska during the late $1960 \mathrm{~s}$, the construction of the Trans-Alaska Pipeline System (TAPS), and the subsequent large-scale extraction and transport of crude oil overland through that pipeline led to the possibility of crude oil spills on terrestrial ecosystems in cold regions. Research was initiated in the early 1970 s to determine the effects of oil spills on vegetation, hydrology, and the physical, chemical, and biological properties of soil in taiga and tundra ecosystems of Alaska and northern Canada (Deneke $e t$ al., 1974; Atlas and Brown, 1978). Most of these studies were short term, generally less than five years, and were usually small scale, on the order of a few square metres (Dickman and Lunardini, 1973; Wein and Bliss, 1973; Everett, 1978; Sexstone et al., 1978; Walker et al., 1978). Only the experimental spills at the Caribou-Poker Creeks Research Watershed near Fairbanks, Alaska (Jenkins et al., 1978; Sparrow et al., 1978; Johnson et al., 1980) and Norman Wells, N.W.T. (Mackay et al., 1974a,b, 1975; Hutchinson et al., 1976; Hutchinson and Freedman, 1978; Hutchinson, 1984) were large enough to simulate the impact expected from a pipeline failure. Only a few studies have looked at very long-term (more than ten years) effects of crude oil spills (e.g., Kershaw and Kershaw, 1986; Hutchinson, 1984).

Each of the two experimental oil spills in Caribou-Poker Creeks Research Watershed north of Fairbanks, Alaska, consisted of $7600 \mathrm{~L}$ of Prudhoe Bay crude oil, with one spill taking place in the winter (February 1976) and the other in the summer (July 1976) (Jenkins et al., 1978; Sparrow et al., 1978; Johnson et al., 1980). The purpose of the spills was to determine the fate and effect of crude oil spilled on the permafrost-underlain black spruce forest of interior Alaska. The oil for each spill was heated to $60^{\circ} \mathrm{C}$ in a closed tank. The $7600 \mathrm{~L}$ of oil was spilled through a $5 \mathrm{~m}$ wide perforated pipe header at the top of a test plot and allowed to flow freely downslope. The winter-spilled oil flowed mostly under the snow along the frozen ground surface, going below the surface only in the spring as the ground thawed. By 1978, total area covered by the winter spill was $188 \mathrm{~m}^{2}$, with $40 \%$ of the winter spill area $\left(75 \mathrm{~m}^{2}\right)$ having surface oil visible. In contrast, most of the summer-spilled crude oil flowed into the organic layer and then spread downslope to produce a large subsurface-oiled area. The summer spill covered $303 \mathrm{~m}^{2}$, with only $10 \%$ of the area $\left(30 \mathrm{~m}^{2}\right)$ having visible surface oil (Johnson et al., 1980).

The site was studied intensively prior to and for three years after the oil treatments (Jenkins et al., 1978; Sparrow et al., 1978; Johnson et al., 1980). After three years, average seasonal thaw depths to permafrost increased to about $70 \mathrm{~cm}$ in areas with oil-blackened surfaces versus $57 \mathrm{~cm}$ for the undisturbed control site. There was little or no compositional change in the crude oil in the soil except for loss of volatile fractions near the soil surface. No evidence was obtained for rapid biological degradation of the oil. Within the areas where surface oil flow occurred, vegetation mortality was virtually complete; damage to vegetation overlying subsurface flows was delayed and far less extensive. Overall soil 
microbial activity was increased and some components of the microbial population were increased, while others were decreased in the areas heavily affected by the oil.

Since the initial studies 15 years ago, there has not been a comprehensive reevaluation of long-term effects of the oil at this site on vegetation change or of compositional changes in the crude oil. Collins (1983) found that thaw depths under the spill-affected areas were still increasing 6 years after the spill; whether ground temperature equilibrium had been reached was not known. Sparrow and Sparrow (1988) studied selected soil chemical and microbiological properties in the heavily impacted portions of the site; they found that microbial biomass and activity and nutrient recycling were lower than in the control plot.

In 1991 the objectives were to assess long-term effects of the oil spills on permafrost and vegetation, as well as longterm changes in oil chemistry. These experimental spill sites present unique opportunities to study the long-term effects of crude oil on a subarctic black spruce forest ecosystem with cold, wet, permafrost-underlain soils, because the experimental spills were conducted under controlled conditions on a well-characterized site that has since remained undisturbed. By monitoring this site, the ability and resiliency of this ecosystem to recover from a crude oil spill disturbance can be better understood.

\section{SITE DESCRIPTION}

The study area for the two original experimental spills is located in the Caribou-Poker Creeks Research Watershed, $48 \mathrm{~km}$ northeast of Fairbanks (Fig. 1). For the original study, two $10 \times 50 \mathrm{~m}$ plots, with their long axis oriented downslope, were established on a west-facing low-angle slope, east of the confluence of Caribou and Poker creeks. A control plot was located just upslope of the two spill plots. The vegetation in the study area is an open black spruce (Picea mariana [Mill.] Britt., Sterns and Pogg.) forest with trees up to $12 \mathrm{~m}$ in height and $20 \mathrm{~cm}$ in diameter and a total tree canopy cover of less than $60 \%$ (Fig. 2). A shrub understory

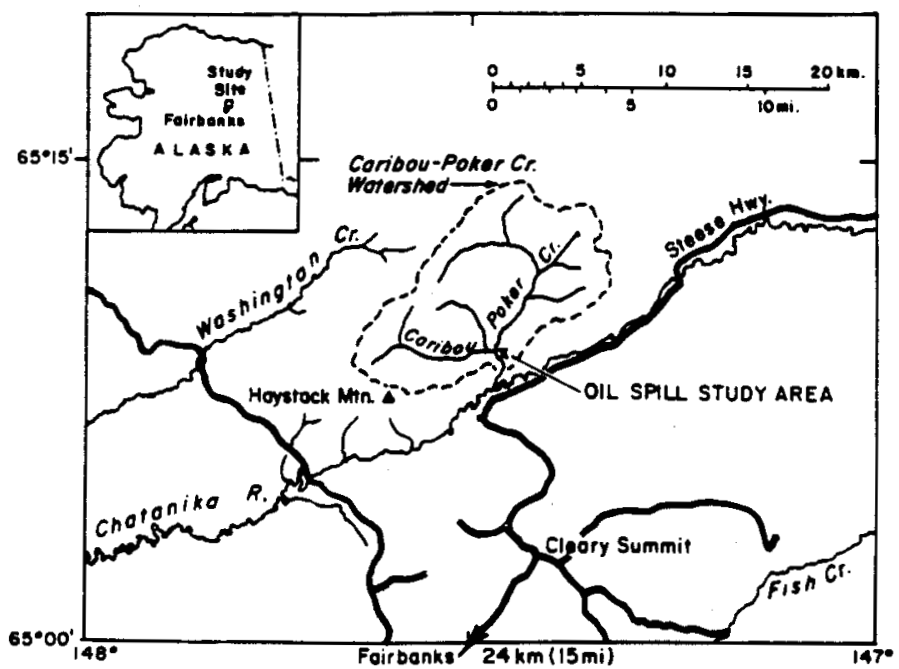

FIG. 1. Caribou-Poker Creeks Research Watershed and experimental crude oil spill site.

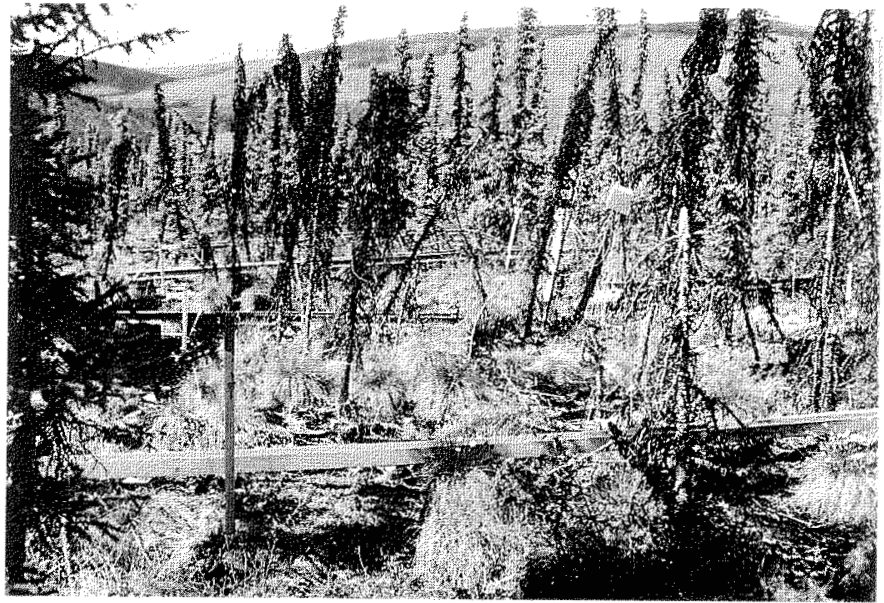

FIG. 2. View in an open black spruce forest looking downslope of an experimental oil spill plot.

includes resin birch (Betula glandulosa Michx.), Labrador tea (Ledum decumbens [Ait.] Hult.), blueberry (Vaccinium uliginosum L.) and willow (Salix sp.). The ground surface is covered with mosses and lichens with scattered (10\%) cotton grass tussocks (Eriophorum vaginatum L.) (Jenkins et al., 1978; Johnson et al., 1980). The study area is underlain by permafrost, with an active layer thickness of $40-60 \mathrm{~cm}$ in undisturbed areas. The soil is a Histic Pergelic Cryaquept. A representative soil profile consists of a $5 \mathrm{~cm}$ moss and lichen surface layer above a $15 \mathrm{~cm}$ undecomposed fibrous peat horizon (O1), a $5 \mathrm{~cm}$ decomposed dark brown-to-black peat horizon $(\mathrm{O} 2)$, a $5 \mathrm{~cm}$ very dark grayish-brown silt loam mixed with organic peat horizon (A1), and a grayish-brown silt loam mineral soil (C2) (Reiger et al., 1972).

\section{METHODS}

\section{Physical Movement of Oil}

The rate and extent of oil flow downslope in each of the two spill plots were originally determined by probing the organic and soil layers on a $1 \mathrm{~m}$ grid with thin wood dowels. The presence of the crude oil was readily discerned by sight and smell on the bare wood of the dowel (Jenkins et al., 1978). We again used wood dowels to determine if there was any further downslope movement of the oil past the last mapped boundary.

The vertical positions of oiled zones within the soil profile were noted when soil cores were taken to obtain samples for chemical analysis. Pits were excavated to observe relationships between oil locations, soil profiles, and rooting regimes of various plant species.

\section{Thermal Effects of Oil on Active Layer}

Active layer thicknesses and changes in the depth of thaw were characterized in the original study by six cross sections laid out $1,3,6,9,14$, and $20 \mathrm{~m}$ downslope from the spill point at the top of each spill plot. Probes were made at $1 \mathrm{~m}$ intervals along these cross sections at the end of the thaw season, usually late September. We relocated each of the cross sections and measured the maximum depth of thaw using 
a metal probe rod. Measurements were made at the end of the thaw season, in late September 1990 and early October 1991. The total amount of ground subsidence that has occurred (due to increased thaw depth and the melting of ice-rich permafrost) since the original spills was measured by stretching a horizontal line across the spill plots at each cross section, extending into undisturbed adjacent terrain, and measuring the distance down to the ground surface at $1 \mathrm{~m}$ intervals along the line.

\section{Characterization of Oil in Soil Samples}

In early June 1991, four partially frozen soil cores were collected from both the summer and winter spill sites using a 3 in. $(7.6 \mathrm{~cm})$ coring auger. One core was collected from each of the following areas: 1) areas where oil was visible on the soil surface; 2 ) a subsurface-oiled area immediately downslope from a surface-oiled area; 3 ) a subsurface-oiled area several metres downslope from a surface-oiled area; 4) an area downslope of the spill where oil was not detectable.

The unfrozen portions of each core (generally the top $15 \mathrm{~cm}$ ) were placed in $0.5 \mathrm{~L} \mathrm{I-Chem} \mathrm{glass} \mathrm{sample} \mathrm{jars} \mathrm{and}$ the frozen portions (generally $15-30 \mathrm{~cm}$ ) were placed in $0.95 \mathrm{~L}$ wide-mouth glass jars. An additional sample was collected from the wall of each of the holes left by the auger by inserting a plastic corer $(2 \mathrm{~cm}$ i.d.) horizontally at the interface of the organic and mineral soil layers (O2/A1 interface) and collecting a $20 \mathrm{~mL}$ core (Hewitt et al., 1992). These cores, which were collected for headspace analysis of volatile organics, were immediately placed in a $30 \mathrm{~mL}$ I-Chem Septa-Jar ${ }^{\mathrm{TM}}$ and tightly sealed. All samples were frozen and shipped to CRREL (Hanover, New Hampshire) for chemical analysis.

Samples collected for analysis of volatile organics were equilibrated at room temperature for $24 \mathrm{~h}$. Then a $500 \mu \mathrm{L}$ gas-tight syringe was used to sample the headspace. A sample of the original crude oil collected from a pool at the winter spill site on 4 June 1976, and since stored in a freezer, was placed in a Septa-Jar and equilibrated at room temperature, and the headspace was sampled. All headspace samples were analyzed by capillary flame ionization gas chromatography (J and W GS-Q gas-solid porous polymer open-tubular Megabore column [30 $\mathrm{m} \times 0.53 \mathrm{~mm}]$ ).

Oil was extracted from soil cores as follows. Frozen soil core samples were subsampled using a knife or bandsaw. Each subsample was approximately $50 \mathrm{~g}$. Oil was extracted from the subsamples and fractionated using methods similar to those used in the original study (Johnson et al., 1980). Successive $50 \mathrm{~mL}$ aliquots of chloroform were added to each subsample, allowed to stand $15 \mathrm{~min}$, then filtered into a preweighed beaker. The process was repeated until the chloroform extract was colorless or pale yellow. The chloroform was evaporated and the beaker was reweighed to obtain the mass of the oily residue. Nine samples collected on 19 July 1979 and then stored in a freezer were also extracted for comparison.

Crude oil is a complex mixture of hydrocarbons composed mainly of alkanes (straight chains, branched chains, and cyclic), aromatics (unsaturated cyclic hydrocarbons with one or more rings), asphaltenes (high molecular weight hydrocarbons), and nitrogen-, sulfur-, and oxygen-containing compounds (NSOs). To determine the relative amounts of the major oil components, the oily residue extracted from each soil subsample was fractionated as follows. Approximately $0.25 \mathrm{~g}$ of the oily residue was deasphaltened with pentane and fractionated by silica gel-alumina column chromatography (Johnson et al., 1980). The alkane, aromatic, and NSO fractions were obtained by sequential elution of the column with pentane, toluene, and methanol respectively. The amount of each fraction was determined gravimetrically after solvent evaporation. The alkane fraction from each sample was dissolved in methylene chloride and characterized by capillary flame ionization gas chromatography (HP-1 [100\% di-methylpolysiloxane] capillary column $[25 \mathrm{~m} \times 0.2 \mathrm{~mm} \times 0.33 \mu \mathrm{m}])$. Ratios of pristane $\left(2,6,10,14\right.$-tetramethylpentadecane) to $n-C_{17}$ (heptadecane) were obtained by peak height measurements made on an HP 3396A digital integrator. Based on replicate injections of a single sample, percent-relative standard deviations (\% RSD) were less than $2 \%$. A limited number of the aromatic fractions were analyzed by gas chromatography/mass spectrometry (GC/MS).

\section{Vegetation}

Before and after the 1976 spills, Johnson et al. (1980) characterized the vegetation of both the winter and summer plots using twelve $1 \mathrm{~m}^{2}$ quadrats aligned along each side of the center line down through each plot. During June 1991, we were able to relocate several of these $1 \mathrm{~m}^{2}$ quadrats. These were used to evaluate the condition and recovery of the ground cover, including mosses, lichens, shrubs, and herbaceous species. L.A. Johnson visited the site in August 1991 with us and inspected six of his $1 \mathrm{~m}^{2}$ quadrats. He provided some baseline vegetation data as well as his evaluation of vegetation recovery after 15 years.

The location, height, and condition (ranked as living, dying, or dead) of all black spruce growing in the surface and subsurface-oiled areas of both the summer and winter plots were determined, beginning at the top of each plot and extending downslope $20 \mathrm{~m}$ (the maximum downslope extent of spruce mortality). A dead spruce contained no live (green) needles or branches. A dying spruce contained at least one live branch, but more than $50 \%$ of its foliage and branches were dead. The location of each spruce was recorded according to an $\mathrm{x}$ and $\mathrm{y}$ coordinate system and $\mathrm{a}$ map was plotted and overlaid on a map showing the distribution of surface and subsurface oil. In this way, each tree could be assigned a position in relation to the distribution of crude oil, i.e., 1) within the area of surface oil, 2) within the area of subsurface oil, 3) the edge between subsurface and surface oil or, 4) the edge between no oil and subsurface oil. In addition, all $E$. vaginatum tussocks growing on the surface-oiled areas of the summer and winter spills were counted and mapped, and their height and diameter were measured. 


\section{RESULTS}

\section{Physical Movement of Oil}

For the original study (Jenkins et al., 1978; Johnson et al., 1980), maps were prepared showing the distribution of oil in each of the two spills and emphasizing the total extent of the spills and the visible surface-oiled areas. Figure 3 updates those maps, showing the maximum extent of the surface-oiled versus subsurface-oiled areas as mapped in 1978 and the newly mapped areas in 1991 showing additional subsurface oil movement. Maximum detected additional downslope movement on the winter spill was $1 \mathrm{~m}$ along one lobe and approximately $1 \mathrm{~m}$ between two small lobes. Total increase in subsurface spill area was approximately $2 \mathrm{~m}^{2}$, a $1 \%$ increase in total area since 1978. Maximum additional downslope movement on the summer spill was $1.5 \mathrm{~m}$ along one lobe, for a maximum increase in subsurface spill area of approximately $3 \mathrm{~m}^{2}$, a $1 \%$ increase.

In general, the thickness of the oiled zone within the soil profile thinned downslope on both spills. In the surface-oiled areas of both spills, the oiled zone was thick, going from the surface down to mineral soil. The vertical distribution of subsurface oil varied from just beneath the living moss to a thin zone 20 or more $\mathrm{cm}$ below the surface. The subsurface oil horizon was generally thinner and located at greater depth downslope (more than $10 \mathrm{~m}$ downslope) than upslope. In much of the subsurface-oiled portions of the oil spills, it had moved downslope above and within the decayed peat $(\mathrm{O} 2)$ horizon, above the mineral soil ( $\mathrm{A} 1$ and $\mathrm{C} 2)$. Near the downslope edge of both spills, the oiled zone was

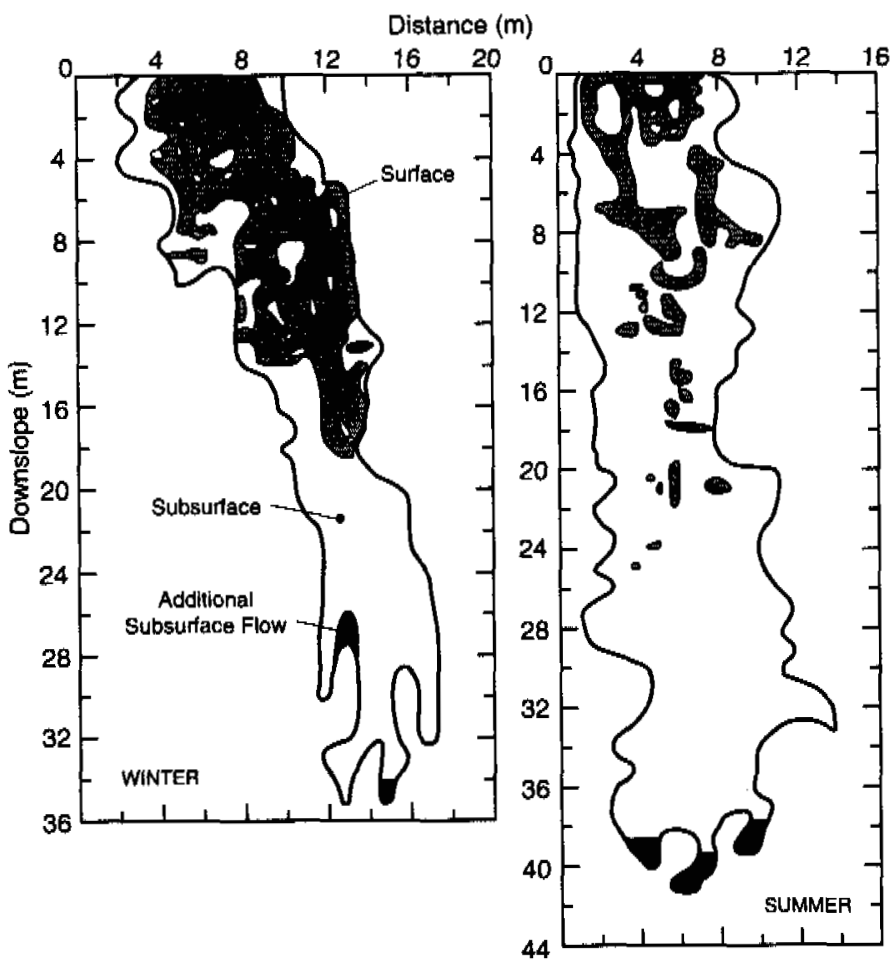

FIG. 3. Plane view of the winter (a) and summer (b) experimental spills showing the maximum extent of the surface-oiled versus subsurface-oiled areas as mapped in 1978 and the areas mapped in 1991, showing additional subsurface oil movement. generally $20-30 \mathrm{~cm}$ below the surface and only $1-2 \mathrm{~cm}$ thick The oil was confined to the $\mathrm{O} 2$ horizon, just above mineral soil. Because the mineral soil was water saturated (with soil moisture ranging from 60 to $100 \%$ by dry weight) throughout the summer thaw season, located as it was just above impermeable frozen soil, the oil was not able to penetrate down into mineral soil to any appreciable degree.

An attempt was made to quantify the spill intensity or oiling density using the amount of oil recovered from samples taken in 1991 and the cross-sectional area of the sample cores. These amounts measured in 1991 give an indication of relative intensity of the spill as a function of distance downslope. Based on these samples, the residual spill intensity was $0.0046 \mathrm{~m}^{3} \cdot \mathrm{m}^{-2}$ near the top of the summer spill in the surface-oiled area. In a subsurface-oiled area near the surfaceoiled area perimeter $15 \mathrm{~m}$ downslope, the intensity had decreased to $0.002 \mathrm{~m}^{3} \cdot \mathrm{m}^{-2}$. It decreased further to $0.0002 \mathrm{~m}^{3} \cdot \mathrm{m}^{-2}$ at $31 \mathrm{~m}$ downslope (subsurface-oiled area) and to $0.00002 \mathrm{~m}^{3} \cdot \mathrm{m}^{-2}$ near the lower edge of the spill. The winter spill shows a similar pattern, decreasing from $0.004 \mathrm{~m}^{3} \cdot \mathrm{m}^{-2}$ near the top of the spill to $0.0021 \mathrm{~m}^{3} \cdot \mathrm{m}^{-2}$ at $24 \mathrm{~m}$ downslope and $0.00001 \mathrm{~m}^{3} \cdot \mathrm{m}^{-2}$ at the lower edge of spill.

\section{Active Layer Thaw Depths}

The average thaw depths for the winter spill were consistently the deepest of the three plots (Fig. 4). Average thaw depths for each of the first three cross sections of each of the three plots are shown as a function of elapsed time. The first three cross sections of each of the two spill plots cover the first $6 \mathrm{~m}$ downslope from the top of the plot where the oil was spilled, the region of the spills with the greatest percentage of surface-oiled area (Fig. 3). The increase in thaw depths between 1982 and 1990 was most dramatic in the winter spill, with its very high percentage of surfaceoiled area. Thaw depths in the summer spill were shallower compared to those in the winter spill; this result is due to

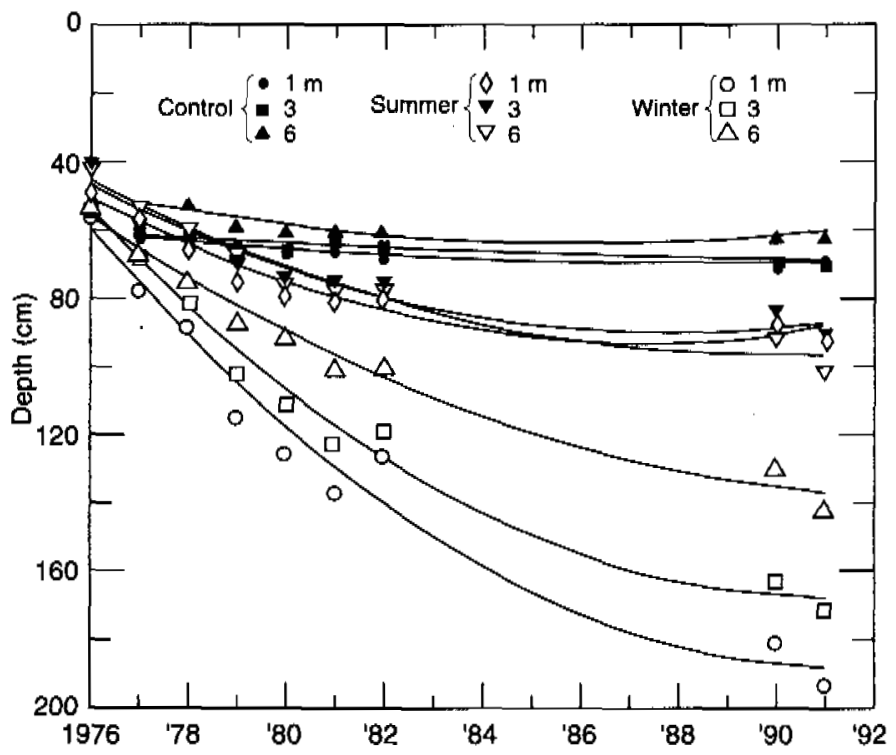

FIO. 4. Average thaw depths for each of the first three cross sections of each of the plots as a function of elapsed time. 
the smaller percentage of surface-oiled area within the summer spill.

Subsidence of the original ground surface occurs when icerich permafrost soil thaws as the active layer thickness increases due to increased heat flux at the surface (Viereck, 1982). The increased heat flux into the ground was possibly due to the much lower albedo of the oil-blackened moss surface (Fig. 5) and the decreased insulation of the thinner, now-dead moss layer, which resulted in deeper thaw of the active layer. Subsidence was cumulative as the active layer continued to increase year after year, as occurred in the winter spill. The subsidence was greatest in the winter spill in the upper area of the slope, with its greatest percentage of surfaceblackened moss. In the winter spill, subsidence along the 1 and $3 \mathrm{~m}$ cross sections was as much as $60 \mathrm{~cm}$. The total effect of the oil spill on permafrost soil would be the sum of the subsidence plus the increased thaw depth (Fig. 6). Subsidence plus active layer depth was greater than $3 \mathrm{~m}$ along the 1 and $3 \mathrm{~m}$ cross sections of the winter spill.

\section{Chemical Characterization of Oil}

Loss of volatiles is the first major process in the weathering of oil after a terrestrial spill (Jenkins et al., 1978; Johnson et al., 1980). Seventeen months after the spill, no volatiles

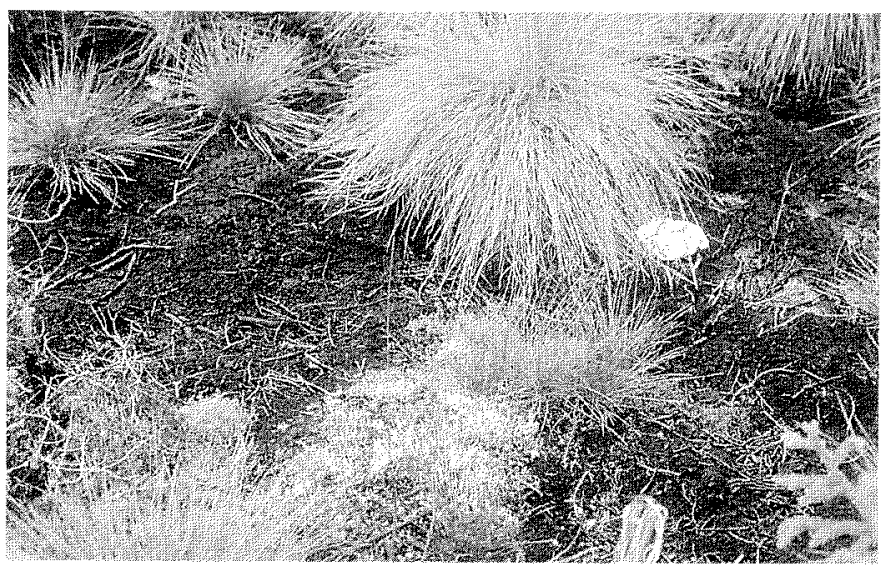

MG. 5. Photograph showing the ofl-blackened surface within the upper part of the winter spill plot.

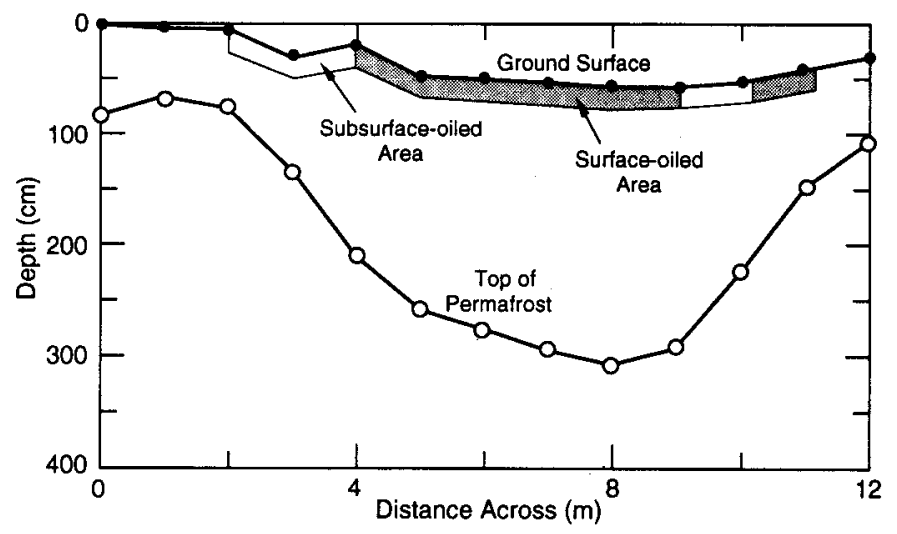

FIG. 6. Profile of the winter $3 \mathrm{~m}$ cross section showing ground subsidence and the active layer thickness. The profile also portrays (not to vertical scale) the distribution along the cross section of surface-oiled and subsurface-oiled areas. were detected in oil from pools on the surface or from oiled moss. However, volatiles were still detectable in the organic and mineral soils, indicating retention of these compounds longer than was originally thought probable (Sexstone et al., 1978; Johnson et al., 1980).

We collected samples at the O2/A1 interface 15 years after the spill. In a sample from the winter spill subsurface-oiled area $24 \mathrm{~m}$ downslope (sample 10, Table 1), collected at a depth of $14 \mathrm{~cm}$, volatiles (C5-C9) were still detectable (Fig. 7c). Retention of these compounds for this length of time was unexpected and indicates that the flux of air is very limited at certain locations in the spill area. Two other samples, one collected in August 1991 one metre away from the first sample and a sample collected from the summer spill at a depth of $15 \mathrm{~cm}$, also contained volatiles (Fig. 7b).

Previously (Johnson et al., 1980), relative changes over time in the composition of the oil were assessed using two different methods. For the first method, the ratio of the alkane to aromatic fraction was computed. Since the alkane fraction tends to degrade microbially at a faster rate than the aromatic fraction, this ratio should decrease over time as the oil degrades. For the second method, the ratio of pristane to $n-\mathrm{C}_{17}$ was used as an indicator of microbiological degradation. Since straight chain alkanes, such as $n-C_{17}$, are more easily metabolized than branched chain alkanes, such as pristane, this ratio is expected to increase with time. Johnson et al. (1980:19) reported "very little or no compositional change through the first two years after the spill with respect to these parameters." Therefore, as of 1978, microbial activity had not modified the alkane fraction of the oil to any great extent.

For samples collected in June 1991, the ratios of pristane to $\mathrm{n}^{-\mathrm{C}_{17}}$ (Table 1), as well as the gas chromatograms (Fig. 8), indicated major compositional changes in some samples collected in June 1991 and almost no change in others. In general, samples collected close to the surface were more degraded than deeper samples. For example, at a surfaceoiled site on the summer spill (samples 22-24), little n- $C_{17}$ was detectable at the surface $(0-8 \mathrm{~cm})$; the pristane-to-n $-\mathrm{C}_{17}$ ratio was 10.6 . At 8 to $15 \mathrm{~cm}$ depth, the pristane-to-n- $\mathrm{C}_{17}$ ratio was 1.03 , while deeper, at $15-23 \mathrm{~cm}$, the ratio was 0.83 . These ratios were all greater than the ratio 0.55 measured for the original oil. Since alkanes are metabolized aerobically, the trend of decreasing pristane-to-n- $\mathrm{C}_{17}$ ratios with depth reflects decreasing oxygen availability. For the subsurface samples collected $24 \mathrm{~m}$ downslope on the winter spill (samples 9,10), degradation of the oil was insignificant; pristane-to-n- $\mathrm{C}_{17}$ ratios were 0.79 and 0.53 at $8-14 \mathrm{~cm}$ and $14-16 \mathrm{~cm}$ respectively. The presence of volatiles at this site confirms little compositional change in the oil.

The alkane-to-aromatic ratios did not reflect the change in the composition of the oil in the degraded samples, indicating that the aromatic fraction also had changed. The aromatic fraction of some samples was analyzed by GC/MS to identify which compounds had persisted. Samples analyzed included the original crude oil, two samples collected in July 1979 , the two most heavily degraded samples (as indicated by the pristane-to-n- $\mathrm{C}_{17}$ ratio) collected in June 1991 (samples 18 and 22), and the least degraded sample collected in June 
TABLE 1. Alkane-to-aromatic and pristane-to-n- $\mathrm{C}_{17}$ ratios for samples collected from Caribou-Poker Creek crude oil spills in 1991 and 1979

\begin{tabular}{|c|c|c|c|c|c|c|}
\hline Date collected & ID \# & Spill (W-winter, S-summer) & Distance downslope (m) (Depth $[\mathrm{cm}]$ ) & Site type & Alk/Arom & Pris/n-C 17 \\
\hline 4 June 1991 & 1 & $\mathrm{~W}$ & $40(0-13 \mathrm{~cm})$ & No detectable oil & NA & NA \\
\hline 4 June 1991 & 9 & W & $24(8-14 \mathrm{~cm})$ & Subsurface oil & 1.15 & 0.79 \\
\hline 4 June 1991 & 10 & W & $24(14-16 \mathrm{~cm})$ & Subsurface oil & 1.36 & $0.53 \dagger$ \\
\hline 4 June 1991 & 12 & $\mathrm{~W}$ & $24(20-35 \mathrm{~cm})$ & Subsurface oil & $*$ & $*$ \\
\hline 4 June 1991 & 18 & W & $2(0-8 \mathrm{~cm})$ & Surface oil & 1.22 & 2.5 \\
\hline 4 June 1991 & 19 & W & $2(8-15 \mathrm{~cm})$ & Surface oil & 1.37 & 0.8 \\
\hline 4 June 1991 & 27 & W & $18(8-15 \mathrm{~cm})$ & Subsurface oil & 1.66 & 1.45 \\
\hline 4 June 1991 & 28 & W & $18(15-28 \mathrm{~cm})$ & Subsurface oil & $*$ & $*$ \\
\hline 4 June 1991 & 4 & $\mathrm{~S}$ & $44(0-10 \mathrm{~cm})$ & No detectable oil & NA & NA \\
\hline 4 June 1991 & 15 & $\mathbf{S}$ & $31(8-16 \mathrm{~cm})$ & Subsurface oil & 1.36 & 1.68 \\
\hline 4 June 1991 & 16 & $\dot{S}$ & $31(16-30 \mathrm{~cm})$ & Subsurface oil & $*$ & $*$ \\
\hline 4 June 1991 & 22 & $\mathbf{S}$ & $2(0-8 \mathrm{~cm})$ & Surface oil & 1.07 & 10.6 \\
\hline 4 June 1991 & 23 & $S$ & $2(8-15 \mathrm{~cm})$ & Surface oil & 1.42 & 1.03 \\
\hline 4 June 1991 & 24 & $\mathbf{S}$ & $2(15-23 \mathrm{~cm})$ & Surface oil & 1.68 & 0.83 \\
\hline 4 June 1991 & 31 & $S$ & $16(8-18 \mathrm{~cm})$ & Subsurface oil & 2.85 & 1.03 \\
\hline 4 June 1991 & 32 & $\mathbf{S}$ & $16(18-30 \mathrm{~cm})$ & Subsurface oil & $*$ & $*$ \\
\hline 4 June 1991 & & $\mathbf{S}$ & $22(10 \mathrm{~cm})$ & Subsurface oil & 1.81 & $0.56 \dagger$ \\
\hline 19 July 1979 & & $\mathbf{W}$ & 33 (duff) & Subsurface oil & 1.37 & 0.56 \\
\hline 19 July 1979 & & W & 9 (moss) & Surface oil & 1.64 & 0.86 \\
\hline 19 July 1979 & & W & 9 (duff) & Surface oil & 1.68 & 0.57 \\
\hline 19 July 1979 & & W & 9 (mineral) & Surface oil & 1.28 & 0.55 \\
\hline 19 July 1979 & & $\mathbf{S}$ & 7 (moss) & Surface oil & 1.43 & 0.68 \\
\hline 19 July 1979 & & $\mathbf{S}$ & 7 (duff) & Surface oil & 1.28 & 0.53 \\
\hline 19 July 1979 & & $\mathbf{S}$ & 42 (moss) & Subsurface oil & 1.55 & 0.51 \\
\hline 19 July 1979 & & $\mathbf{S}$ & 42 (duff) & Subsurface oil & 1.26 & 0.53 \\
\hline 4 June 1976 & & Crude oil from pool & & & 1.07 & $0.55+$ \\
\hline 4 June 1976 & & $\begin{array}{l}\text { Oiled moss taken from } \\
\text { very beginning of oil spill }\end{array}$ & & & 1.35 & $0.56 \dagger$ \\
\hline
\end{tabular}

* Too little oil extracted for accurate ratio measurements.

† Volatiles detected in these samples.

1991 (sample 10). Chromatograms (Fig. 9) show a significant change in the degraded samples (samples 18 and 22). Specifically, there was a decrease in the relative amounts of the lower molecular weight aromatics (naphthalenes) compared to the higher molecular weight aromatics (phenanthrenes). The highest peak in the chromatograms from each of these degraded samples was identified as 2,5-dimethylphenanthrene, a chemical known to be persistent in the environment (Bossert and Bartha, 1984).

\section{Vegetation Mortality and Recovery}

Where the black, asphalt-like surface oil residue was present, there was scant live vegetation cover. Most mosses, lichens, and shrubs were killed soon after the original spills (Johnson et al., 1980), and, with few exceptions, the only vegetation on the surface-oiled area was scattered tussocks of $E$, vaginatum. By late August, when tussock leaf growth had reached its maximum extent, these covered about 50-65\% of the surface-oiled area of both the winter and summer spills. Fifty-eight living tussocks were counted on the surface-oiled area of the winter spill $\left(0.8 \cdot \mathrm{m}^{-2}\right)$ and 39 were located on the surface-oiled area $\left(1.3 \cdot \mathrm{m}^{-2}\right)$ of the summer spill. Based on the size distribution of the diameters of these tussocks (Fig. 10), the tussocks are younger on the summer spill than the winter spill, and some may have become established during the past 15 years. In addition, comparison of photos taken before the spills of permanent $1 \mathrm{~m}^{2}$ quadrats established by L.A. Johnson (Johnson et al., 1980) show that many of the $E$. vaginatum tussocks present at the time of the spill increased dramatically in size and even flourished (Fig. 11).
Most of the associated dwarf shrubs visible in 1976 have disappeared.

Three tussocks on the surface-oiled area of the winter spill were excavated. The annual root system of these tussocks grew down through the oiled organic horizon into the mineral soil. The tightly packed root mass suggested possible resistance to oil penetration. However, chloroform extraction of a portion of one root mass showed the presence of oil, suggesting that the annually produced roots are capable of penetrating down through the oiled horizon to reach unoiled mineral soil. No oil was measured within root tissue.

A few areas of surface oil have a sparse cover of fruticose lichens, including primary squamules and occasional mosses (Polytrichum sp.). Where there is subsurface oil only, it is difficult to detect any changes in the ground cover.

The number of black spruce trees in the upper $12 \times 20 \mathrm{~m}$ area of both spill plots were very similar (151 on the winter spill plot versus 155 on the summer spill plot). Eighty-two of these trees were located on the oiled area (either surface or subsurface oil) of the winter plot; coincidentally, 82 also were counted on the surface or subsurface-oiled areas of the summer plot. (None of the trees outside the oiled area on either spill plot were dead.) Of these trees, more than half (56\%) were dead on the winter spill, compared with $38 \%$ on the summer spill (Fig. 12). On both spills, an additional $27-30 \%$ of the trees appeared to be dying. Therefore, only $18 \%$ of the trees were alive and appeared healthy on the winter spill, compared to $33 \%$ alive and healthy on the summer spill. No black spruce seedlings were counted in either plot, although cones were noted on many of the trees. 
a.

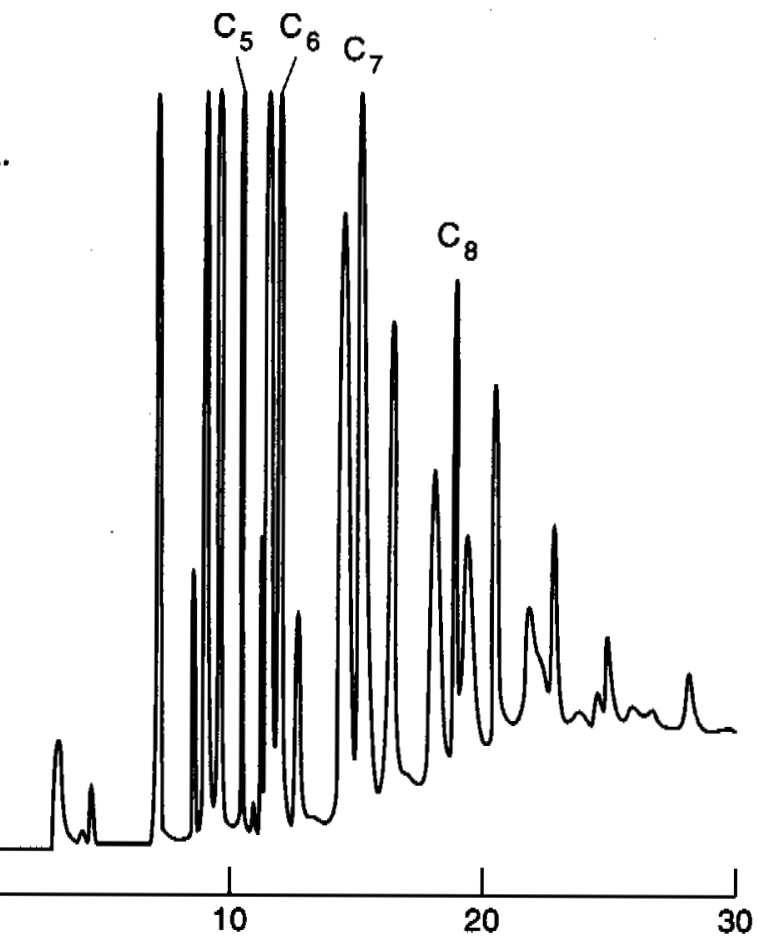

b.

c.

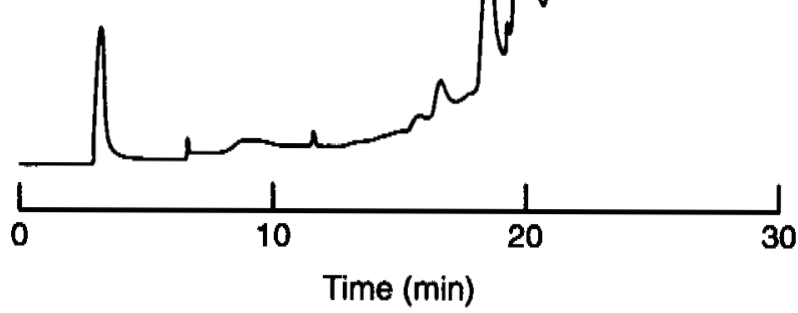

FIG. 7. Headspace chromatograms. a) Oil taken from a pool on the winter spill site in June 1976. b) Oily soil from $22 \mathrm{~m}$ downslope on summer spill (15 cm deep) in August 1991. c) Oily soil from $24 \mathrm{~m}$ downslope on winter spill (15 cm deep) in August 1991 .
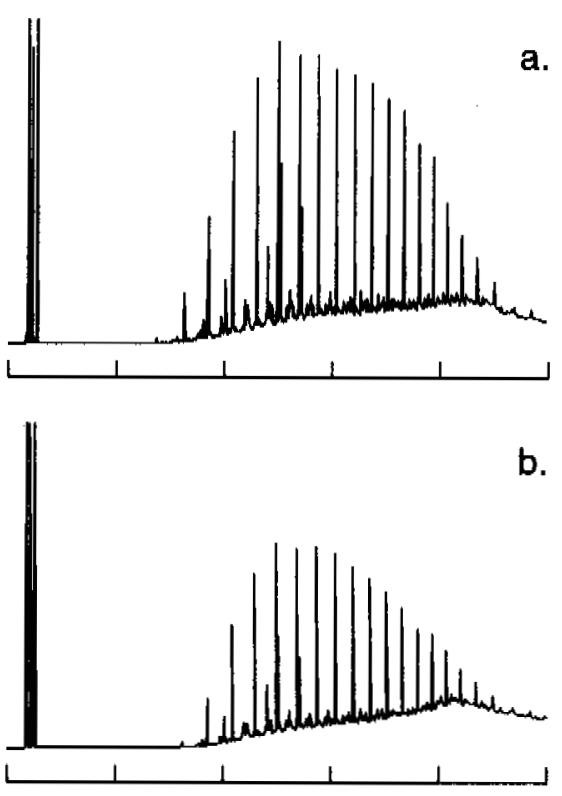

c.

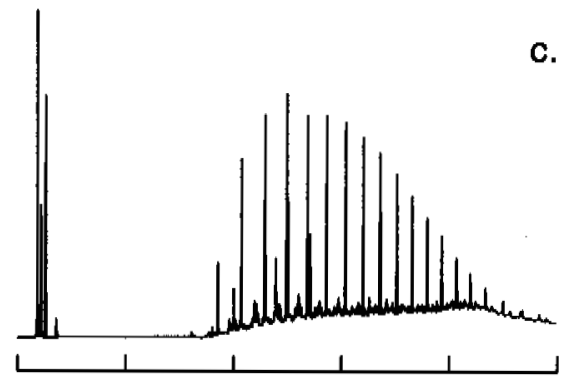

d.

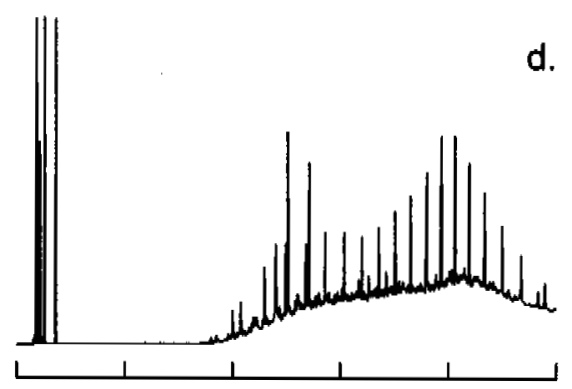

e.

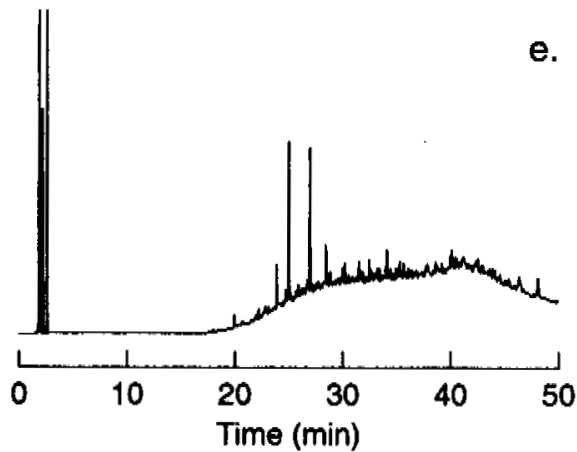

FIG. 8. Chromatograms of alkane fractions showing composition of original crude oil and compositional changes in samples collected in 1979 and 1991 . a) Original crude oil. b) Oily moss collected in July $1979(\mathrm{~S}-4,7)$, showing little change from original oil, c) Subsurface sample $(14-16 \mathrm{~cm})$ collected June 1991, $24 \mathrm{~m}$ downslope on winter spill, showing little change from original oil. d) Surface $(0-8 \mathrm{~cm})$ sample collected June $1991,2 \mathrm{~m}$ downslope on winter spill, showing significant weathering. e) Surface $(0-8 \mathrm{~cm})$ sample collected June 1991, 2 m downslope on summer spill, showing significant weathering. 

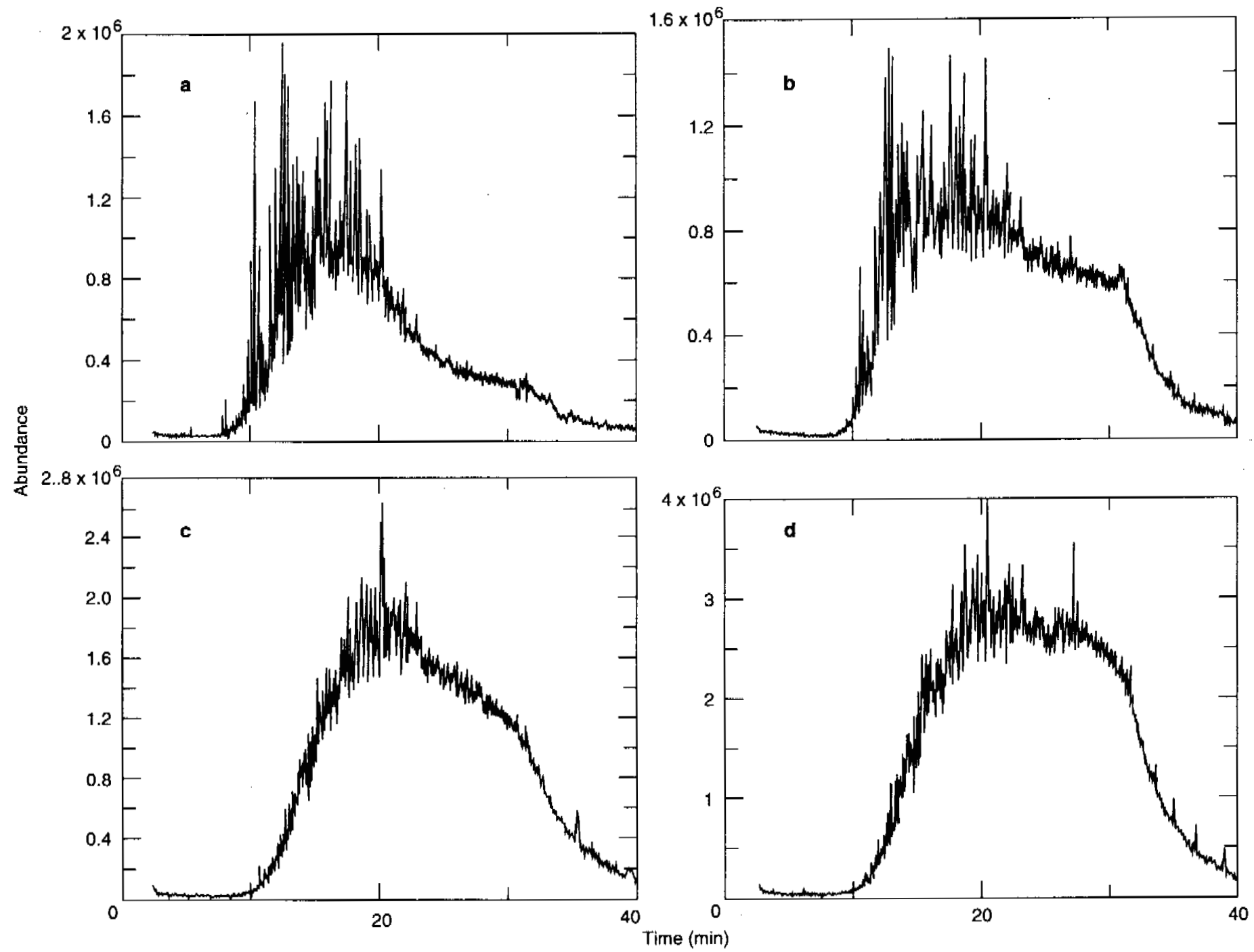

FIG. 9. Chromatograms of aromatic fractions showing compositional changes. a) Extract duff sample collected July 1979. b) Subsurface sample (\#10) collected June 1991. c) Surface sample ( $\$ 22)$ collected June 1991. d) Surface sample (\#18) collected June 1991.

No sign of black spruce recovery, either in terms of new seedling establishment or new growth on damaged trees, was noted.

Almost all the dead trees on the summer spill were located in the upper $10 \mathrm{~m}$ of the plot, with one dead spruce $15 \mathrm{~m}$ downslope. On the winter spill, the last dead spruce was $20 \mathrm{~m}$ downslope, and significant numbers of the dead trees occurred in both the first and second $10 \mathrm{~m}$ of the plot. The location of dead black spruce trees is highly correlated with the distribution of surface-oiled areas (Fig. 13). No live spruces occurred on areas of surface oil. On the winter spill, most of the dead trees were located in or on the edge of areas with surface oil. On the summer spill, most of the dead trees are located either on the edge between surface and subsurface oil, or on islands of subsurface oil within the surface oil perimeter.

The numbers of dead black spruce in 1990 and 1991 can be compared with those in 1977 and 1978 (Fig 14). Before the spill in 1976, there were no dead trees in either plot. One year after the spill (1977) Jenkins et al. (1978) reported
30 dead black spruce on the summer spill, compared with 24 on the winter spill. By July 1978, an additional 2 trees had died on the summer spill, while 10 additional trees died on the winter spill. They concluded that, two years after the spill, vegetation damage appeared more rapidly and was more extensive on the summer spill. Our counts in 1991 showed that during the past 13 years, only an additional 2 trees have died on the summer spill plot, while 14 more have died on the winter spill plot. A total of 34 trees have died on the summer spill, or $0.24 \cdot \mathrm{m}^{-2}$ of oiled area, while 48 , or $0.41 \cdot \mathrm{m}^{-2}$, have died on winter spill. The downslope extent of dead black spruce trees has increased by $5 \mathrm{~m}$ on the summer spill during the past 13 years but has not changed since 1978 on the winter spill.

Excavation of 2 live spruce trees on the summer spill showed the location of oil in relation to the distribution of the tree roots. The 2 excavated root systems were near the surface $(0-7 \mathrm{~cm})$ in the $\mathrm{O} 1 \mathrm{~h}$ horizon, apparently permitting survival of the 2 trees in the unoiled organic horizon above the oiled zone in the $\mathrm{O} 2$ horizon. 

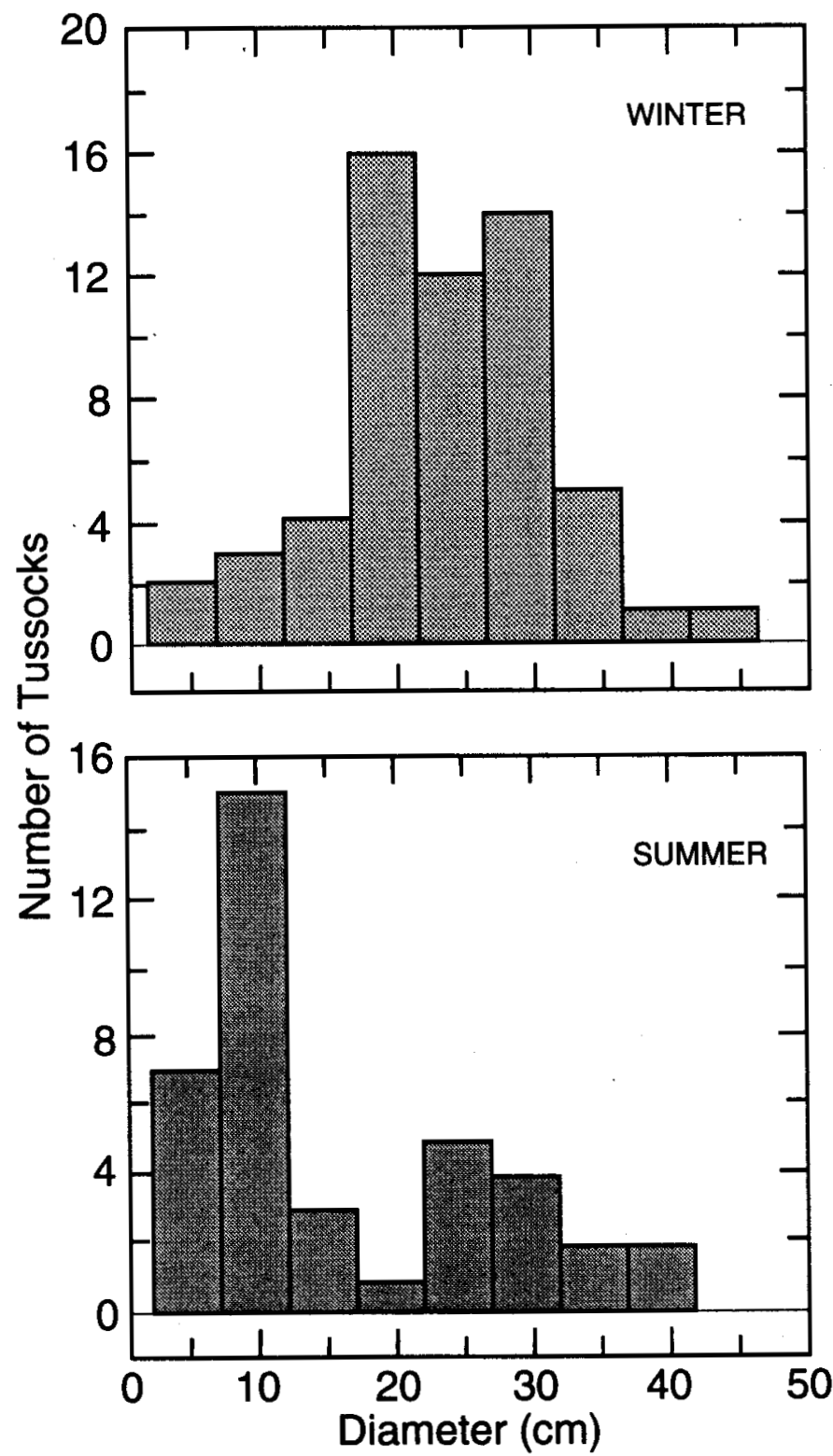

FIG. 10. Diameter frequency distribution of $E$. vaginatum tussocks on surface-oiled areas of the 1976 summer and winter experimental crude oil spills measured in August 1991.

\section{DISCUSSION}

Between 1978 and 1991, only minor amounts of additional oil movement occurred in each of the two spills. The small amount of movement demonstrates that the oil is not very mobile. Hutchinson and Freedman (1978) attributed considerable additional horizontal spreading of oil at their experimental large point spill to a large rainfall event four years after the original spill; the unusually large rain event evidently remobilized the oil and increased the spill area by a considerable amount. At least one extreme rainfall event, during the summer of 1989, has occurred in the CaribouPoker Creeks Watershed since the original experimental spill. In addition, large snowmelt runoff events occurred during the springs of 1990 and 1991. None of these events produced significant additional horizontal spreading of the oil. In addition, within the subsurface portions of the spills, there
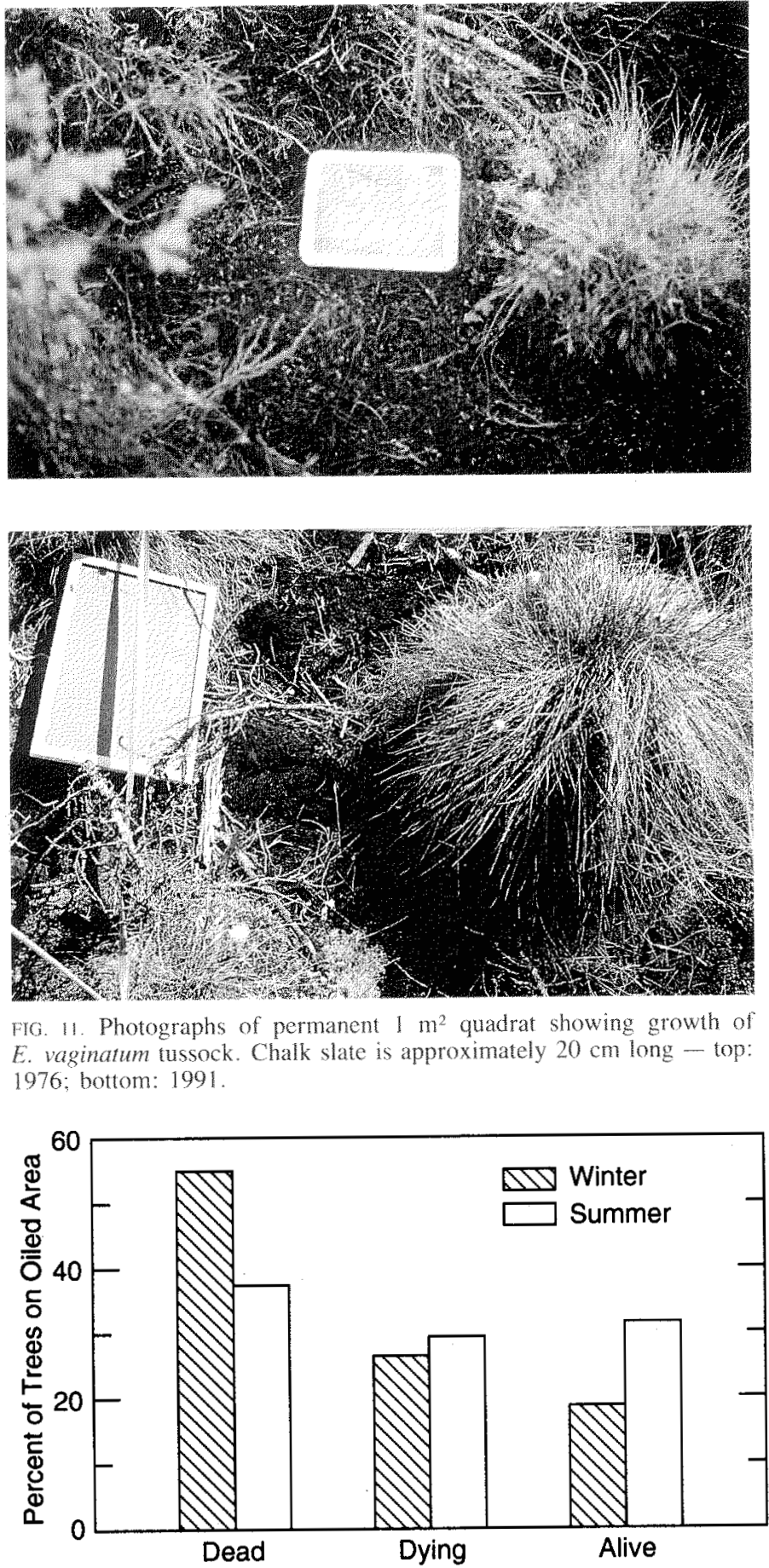

FIG. 12. Condition in 1991 of black spruce trees on surface and subsurfaceoiled areas of the 1976 winter and summer experimental oil spills.

was no indication of any vertical movement of the oil out of the $\mathrm{O} 2$ horizon into the unoiled horizon above it that might have been attributable to rises in the water table.

The large increases in the active layer documented for the winter spill during the last 15 years are much greater and persist much longer than reported for other experimental spills in a permafrost-underlain forested setting (Wein and Bliss, 1973; Mackay et al., 1975; Hutchinson et al., 1976; Hutchinson and Freedman, 1978). Hutchinson (1984), however, 


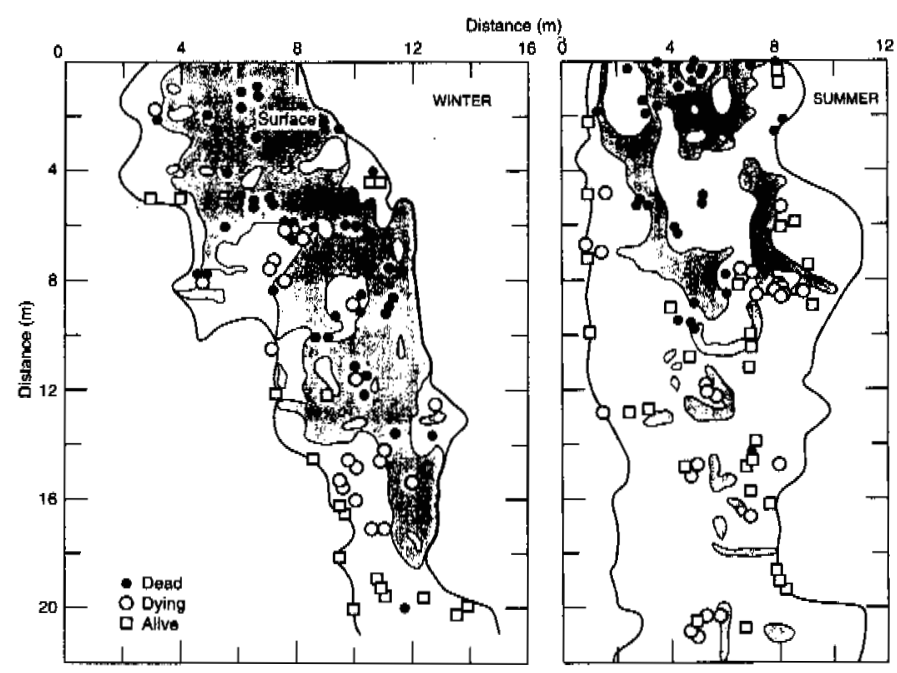

FIG. 13. Map of black spruce trees. a) Winter spill plots. b) Summer spill plots.

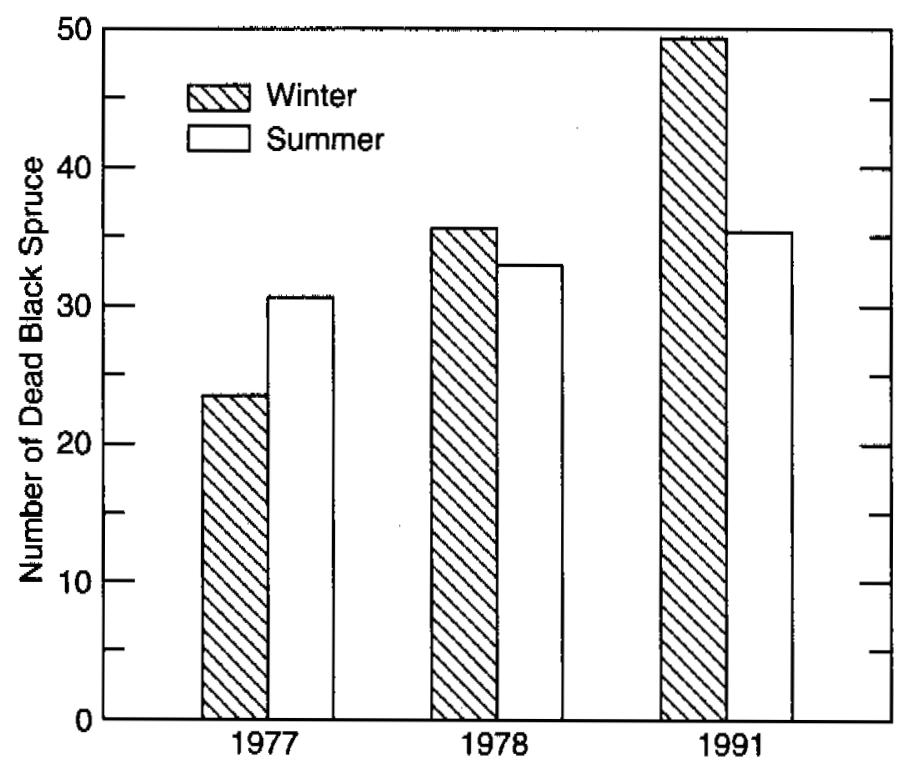

FIG. 14. Number of dead black spruce trees in 1977, 1978, and 1991 on the winter and summer experimental oil spills.

reported significant increases in the thaw depth of his experimental diesel spray spill compared to the control (85 versus $50 \mathrm{~cm}) 15$ years later and lower but significant increases in the crude oil spray spill in the burnt forest site. He attributed the increase in the diesel plot to the more severe effect of the diesel compared to the crude oil upon the ground flora. The Norman Wells sites had gravelly soils, which made probing of the active layer difficult, unlike the fine-grained soils at our site.

The deep thaw in the upper part of the winter spill was due to the large concentration of oil within the upper organic horizons of the soil, the almost total death of plants within this area (except for $50 \%$ cover by $E$. vaginatum tussocks by August), and the resulting extensive blackened surfaceoiled areas, which must have caused a major change in the surface albedo. The presence of crude oil modifies the ground surface heat flux in a number of ways, any or all of which may be causing the increased thaw. These effects include: 1) the decreased albedo of the oiled surface leading to surface heating; 2) the removal of tree canopy due to the death of black spruce, thus increasing solar radiation penetration to the surface; 3) the alteration of thermal diffusivity of the organic layer by presence of oil; and 4) compaction of the now-dead insulating organic layer.

Mackay et al. (1975) and Wein and Bliss (1973) discuss these factors as they apply to their experimental spills and attempt to model the maximum effects on thaw depth increases. The depths they predicted and measured are considerably less than those measured by us, with the differences most likely due to different soil type (gravelly soil versus ice-rich silt) and our longer-term measurements. The thaw depths we measured are similar, however, to those measured after mechanical and fire disturbance in other black spruce forested sites in interior Alaska (Dyrness, 1982; Viereck, 1982). However, the vegetation recovery following a fire disturbance and the subsequent stabilization and recovery of the active layer was faster than for the oil spill sites (Van Cleve and Viereck, 1983).

Little or no microbial or other types of weathering of crude oil were apparent in samples collected up to July 1978 (Johnson et al., 1980) or in the samples collected in July 1979; significant weathering was found in some samples collected in June 1991. Surface samples were more degraded than subsurface samples, suggesting that warmer surface soils and aerobic microbiological activity were responsible for some of the changes in oil composition. Retention of volatile compounds in some subsurface samples indicates that the flux of air is very limited at certain locations in the spill area. Conversely, the organic soils in which the oil was found, above the saturated mineral soil, appeared to be well aerated when examined visually in late June and August 1991. The lack of extenisive peat decomposition in these types of soils seems more related to cold temperature and slow rates of annual thaw than to low oxygen supplies (Neiland and Viereck, 1977). The presence of volatile organics in samples collected from the winter and summer spills 15 years after the original spills was illustrative of just how persistent crude oil can be when spilled on permafrost-underlain soils.

The 1976 crude oil spills killed most of the vegetation on the surface-oiled areas. Black spruce was particularly sensitive to the presence of crude oil in the root zone, and mortality was $100 \%$ in surface-oiled areas. In addition, there was little or no recovery of shrubs on the surface-oiled areas; only cotton grass tussocks that survived the initial spill have regrown vigorously, probably due in part to competitive release. Fetcher and Shaver (1982) and Fetcher (1985) showed that the tillering and flowering of $E$. vaginatum tussocks increased with decreasing competition or cover by shrubs and mosses. The surface oil acted to kill the mosses and shrubs surrounding the tussocks and thereby removed the shading caused by shrubs. Tussocks may be resistant to oil due to their raised growth form and their annual root regrowth that penetrates the oiled horizon to reach the mineral soil by late summer (Chapin et al., 1979; Johnson et al., 1980). Mosses and lichens are particularly adept at floating over the surface, even on surface-oiled areas, and there is 
evidence of some lateral growth in some areas after 15 years. The lateral growth occurs from individuals on raised features that were not oiled, such as tussock and tree bases.

Although oil covered a larger total area on the summer than on the winter spill, most of the oil flowed beneath the surface. Subsurface oil at a depth greater than $10 \mathrm{~cm}$ on both the summer and winter spills produced little detectable effect on the vegetation. Soil profiles and excavation of spruce root systems show that roots were confined to surface organic layers. On the summer spill, most of the oil was located below the surface, so that many shallow-rooted black spruces were able to survive in the shallow, $5-15 \mathrm{~cm}$ thick organic $\mathrm{O} 1$ horizon above the oiled zone in the $\mathrm{O} 2$ horizon. The observed rooting depths of most species of trees and shrubs that grow in this type of forest were shallow enough to avoid the predominantly subsurface oil found on the summer spill. Hutchinson (1984), however, found an increasing area of dead plants over the subsurface portions of the Norman Wells, Northwest Territories, spill in a black spruce forest. The area of dead vegetation had increased from $60 \mathrm{~m}^{2}$ to $200 \mathrm{~m}^{2}$ after four years.

Because the winter spill produced more than twice as much surface-oiled area as the summer spill, the winter spill had a more drastic overall effect on the vegetation. Jenkins et al. (1978) concluded that the summer spill produced more vegetation damage than the winter spill. The reevaluation of this site 15 years after the spills suggests that the winter spill produced more damage.

Although the effects of the summer spill were almost instantaneous, with all but 2 of the 30 dead trees having died within the first 2 years following the spill, black spruce on the winter spill have continued to die during the past 13 years (since 1978). Thus, the effects of the oil on black spruce have been long term and chronic on the winter spill and were relatively short term and acute on the summer spill. The reason for this continued die-off may be due to the fact that black spruce was dormant at the time of the winter spill but actively growing at the time of the summer spill. There were no measured compositional differences in oil residue between the winter and summer spills that might explain vegetation response differences.

\section{CONCLUSIONS}

Fifteen years following the large oil spills in winter and summer upon a black spruce site, the following observations were made:

1) In both the winter and summer spills, there was minimal additional downslope movement of the oil.

2) The effect of the spills on the underlying permafrost was extensive where the ground surface was blackened by the spills. Because the winter spill produced more surfaceoiled area, increases in active layer thickness and subsidence is greatest on the winter spill.

3) Compositional changes in the oil vary with depth. While oil extracted from surface samples had evidence of microbiological degradation, some subsurface samples had little or no compositional change and even retained volatiles.
4) With the exception of vigorous growth of $E$. vaginatum tussocks, there was no evidence of recovery of vegetation on the surface-oiled areas of either plot.

5) Mortality of black spruce has continued for 15 years on the winter spill plot.

\section{ACKNOWLEDGEMENTS}

Funding for this research was provided by the U.S. Army Cold Regions Research and Engineering Laboratory, Hanover, New Hampshire. The authors acknowledge the advice and assistance provided by Dr. Cindy Brothers, Ms. Elizabeth Nadeau, and Dr. Larry Johnson. Dr. Thomas F, Jenkins and Dr. C.L. Grant technically reviewed the manuscript, and Ms. Gioia Cattabriga provided editorial review.

\section{REFERENCES}

ATLAS, R.M., and BROWN, J. 1978. Introduction to the workshop on ecological effects of hydrocarbon spills in Alaska. Arctic 31(3): 155-157.

BOSSERT, I., and BARTHA, R. 1984. The fate of petroleum in soil ecosystems. In: Atlas, R.M., ed. Petroleum microbiology. Chap. 10. New York: Macmillan Publishing Co. 435-473.

CHAPIN, F.S., III, VAN CLEVE, K., and CHAPIN, M.C. 1979. Soil temperature and nutrient cycling in the tussock growth form Eriophorum vaginatum. Journal of Ecology 67:169-189.

COLLINS, C.M. 1983. Long-term active layer effects of crude oil spilled in interior Alaska. In: Permafrost: Proceedings of the Fourth International Conference on Permafrost. Washington, D.C.: National Academy Press. 175-179.

DENEKE, F.J., McCOWN, B.H., COYNE, P.I., RICKARD, W, and BROWN, J. 1974. Biological aspects of terrestrial oil spills: USA CRREL oil research in Alaska, 1970-1974. Research Report 346. Hanover, New Hampshire: U.S. Army Cold Regions Research and Engineering Laboratory.

DICKMAN, M., and LUNARDINI, V. 1973. Some effects of a deliberate small-scale oil spill on the overlying vegetation and the thaw depth near Inuvik, NWT. In; Mackay, D., and Harrison, W., eds. Oil and the Canadian environment. Toronto: University of Toronto, Institute of Environmental Sciences and Engineering.

DYRNESS, C.T. 1982. Control of depth to permafrost and soil temperature by the forest floor in black spruce/feathermoss communities. Research Note PNW-396. Fairbanks, Alaska: U.S. Department of Agriculture, Forest Service, Pacific Northwest Forest and Range Experiment Station.

EVERETT, K.R. 1978. Some effects of oil on the physical and chemical characteristics of wet tundra soils. Arctic 31(3):260-276.

FETCHER, N. 1985. Effects of removal of neighboring species on growth, nutrients, and microclimate of Eriophorum vaginatum. Arctic and Alpine Research 17:7-17.

FETCHER, N., and SHAVER, G.R. 1982. Growth and tillering patterns within tussocks of Eriophorum vaginatum. Holarctic Ecology 5:180-186.

HEWITT, A.D., MIYARES, P.H., LEGGETT, D.C., and JENKINS, T.F. 1992. Comparison of analytical methods for the determination of volatile organic compounds in soils. Environmental Science and Technology 26:1932-1938.

HUTCHINSON, T.C. 1984. Recovery of arctic and subarctic vegetation nine summers after crude oil and diesel spills. Environmental Studies No. 22. North of 60. Ottawa: Department of Indian Affairs and Northern Development.

HUTCHINSON, T.C., and FREEDMAN, W. 1978. Effects of experimental crude oil spills on subarctic boreal forest vegetation near Norman Wells, N.W.T., Canada. Canadian Journal of Botany 56:2424-2433.

HUTCHINSON, T.C., HELLEBUST, J.A., and TELFORD, M. 1976. Oil spill effects on vegetation and soil microfauna at Norman Wells and Tuktoyaktuk, N.W.T. ALUR 1974-75. North of 60. Ottawa: Department of Indian Affairs and Northern Development.

JENKINS, T.F., JOHNSON, L.A., COLLINS, C.M., and McFADDEN, T.T. 1978. The physical, chemical, and biological effects of crude oil spills on black spruce forest, interior Alaska. Arctic 31:305-323.

JOHNSON, L.A., SPARROW, E.B., JENKINS, T.F., COLLINS, C.M., DAVENPORT, C.V., and McFADDEN, T.T. 1980. The fate and effect of crude oil spilled on subarctic permafrost terrain in interior Alaska. 
CRREL Report 80-29. Hanover, New Hampshire: U.S. Army Cold Regions Research and Engineering Laboratory.

KERSHAW, G.P., and KERSHAW, L.J, 1986. Ecological characteristics of 35-year-old crude-oil spills in tundra plant communities of the Mackenzie Mountains, N.W.T. Canadian Journal of Botany 64(12):2935-2947.

MACKAY, D. , CHARLES, M.E., and PHILIPS, C.R. 1974a. The physical aspects of crude oil spills on northern terrain. Report no. 73-42. Environmental-Social Committee, Northern Pipelines, Task Force on Northern Oil Development. Ottawa: Information Canada.

MACKAY, D., CHARLES, M.E., and PHILIPS, C.R. 1974b. The physical aspects of crude oil spills on northern terrain (Second Report). Report No. 74-25. Environmental-Social Committee, Northern Pipelines, Task Force on Northern Oil Development. Ottawa: Information Canada.

MACKAY, D., CHARLES, M.E., and PHILIPS, C.R. 1975. The physical aspects of crude oil spills on northern terrain (Final Report). ALUR 74-75-85. North of 60. Ottawa: Department of Indian Affairs and Northern Development.

NEILAND, B.J., and VIERECK, L.A. 1977. Forest types and ecosystem in North American forest lands at latitudes north of 60 degrees. In: North American forest lands at latitudes north of 60 degrees. Proceedings of a symposium held at University of Alaska Fairbanks, 19-22 September 1977. 109-136.

RIEGER, S., FURBUSH, C.E., SCHOEPHORSTER, D.B., SUMMERFIELD, H., Jr., and GEIGER, L.C. 1972. Soils of the Caribou-Poker Creeks Research Watershed, interior Alaska. Technical
Report 236. Hanover, New Hampshire: U.S. Army Cold Regions Research and Engineering Laboratory.

SEXSTONE, A., GUSTIN, P., and ATLAS, R.M. 1978. Long-term interactions of microorganisms and Prudhoe Bay crude oil in tundra soils at Barrow, Alaska. Arctic 31(3):348-354.

SPARROW, E.B., DAVENPORT, C.V., and GORDON, R.C. 1978. Response of microorganisms to hot crude oil spills on a subarctic taiga soil. Arctic 31(3):324-338.

SPARROW, S.D., and SPARROW, E.B. 1988. Microbial biomes and activity in a subarctic soil ten years after crude oil spill. Journal of Environmental Quality 17:304-309.

VAN CLEVE, K., and VIERECK, L.A. 1983. A comparison of successional sequences following fire on permafrost-dominated and permafrostfree sites in interior Alaska. In: Permafrost: Proceedings of the Fourth International Conference on Permafrost. Washington, D.C.: National Academy Press. 175-179.

VIERECK, L.A. 1982. Effects of fire and firelines on active layer thickness and soil temperatures in interior Alaska. In: Proceedings, 4th Canadian Permafrost Conference. 123-135.

WALKER, D.A., WEBBER, P.J., EVERETT, K.R., and BROWN, J. 1978. Effects of crude and diesel oil spills on plant communities at Prudhoe Bay, Alaska, and the derivation of oil spill sensitivity maps. Arctic 31(3):242-259.

WEIN, R.W., and BLISS, L.C. 1973. Experimental crude oil spills on arctic plant communities. Journal of Applied Ecology 10:671-682. 